\title{
LETTER
}

\section{Genomic Structure of the Human OB Receptor and Identification of Two Novel Intronic Microsatellites}

\author{
Wendy K. Chung, ${ }^{1}$ Loraine Power-Kehoe, ${ }^{1}$ Melvin Chua, ${ }^{1}$ Renata Lee, ${ }^{2}$ \\ and Rudolph L. Leibel ${ }^{1,3}$
}

${ }^{1}$ Laboratory of Human Behavior and Metabolism, and ${ }^{2}$ DNA Sequencing Core, The Rockefeller University, New York, New York 10021

Identification of the OB (leptin) receptor (OBR) as the gene that is defective in diabetes (Lepr ${ }^{\text {db }}$ ) mice and fatty (Lepr ${ }^{f g}$ ) rats provides an important candidate gene for the study of the genetics of human obesity. We defined the boundaries of the 18 coding exons for the long form of $O B R$, and sequenced the immediately adjacent intronic regions. These sequences can be used to generate reagents for genetic analysis (e.g., direct sequencing, single-stranded conformational polymorphism analysis, etc.) of the possible role of OBR in the regulation of adiposity in humans. In addition, we have identified two highly polymorphic intronic microsatellites that can be scored with the polymerase chain reaction.

[The sequence data described in this paper have been submitted to GenBank under accession nos. U62487-U62521.]

Obesity is a major and increasing public health problem. At least $25 \%$ of Americans (adults and children) are overweight (Anon. 1994; Kuczmarski et al. 1994). The heritability of body mass index (BMI), a surrogate measure of obesity, has been estimated to be 0.77-0.84 (Stunkard et al. 1986), and the concordance of BMI or skinfold thickness is as high as $74-84 \%$ in monozygotic twins, compared with $22-44 \%$ in dizygotic twins (Bodurtha et al. 1990). Although there is clearly a genetic basis for body fat content, the genes responsible for determining adiposity in humans are not known (Bouchard and Bray 1995).

Five autosomal obesity mutations in miceobese $(o b)$, diabetes $(d b)$, fat $(f a t)$, tubby $(t u b)$, and Yellow (agouti $\mathrm{A}^{\mathrm{y}}$ )-provide novel candidates that may play roles in the genetics of human obesity (Leibel et al. 1995). The cloning of the receptor OBR for the obese gene product (OB or leptin) (OBR) (Tartaglia et al. 1995) and the demonstration that mutations of this receptor are responsible for the diabetes $(d b)$ phenotype in mice (Chen et al. 1996; Lee et al. 1996) and fatty (fa) phenotype in rats (Chua et al. 1996a,b; Iida et al. 1996; Phillips et al. 1996) allow for genetic test-

${ }^{3}$ Corresponding author.

E-MAIL leibel@rockvax.rockefeller.edu; FAX 212-327-7150. ing by means of polymorphic markers located within the gene and by direct sequence analysis of OBR.

OBR has at least five splice variants in mice (Lee et al. 1996). Only one of these splice variants contains an intracytoplasmic domain with box motifs for JAK-mediated signaling (Tartaglia et al. 1995; Ghilardi et al. 1996; Lee et al. 1996). This splice variant with signaling potential is commonly referred to as the long form of OBR.

OBR is located on chromosome $1 \mathrm{p}$ in humans (Chung et al. 1996). We have characterized the genomic structure of OBR and have defined the intronic sequence adjacent to each of the 18 coding exons in the long form of the gene to provide reagents for detecting genomic sequence variants by either direct sequence analysis or other methods of mutation detection such as single-stranded conformational polymorphism (SSCP). We have also identified two polymorphic, repetitive sequence markers within two introns of OBR that should be useful in either linkage or association studies.

\section{RESULTS}

The genomic structure of the OBR long splice variant is outlined in Figure 1. The genomic se- 
GENOMIC STRUCTURE OF THE HUMAN OB RECEPTOR

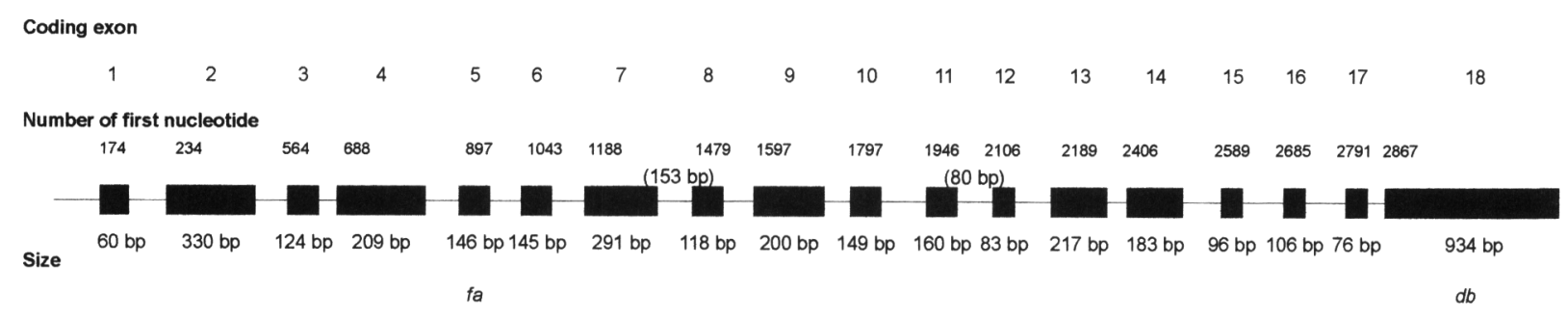

Figure 1 Genomic structure of the long form of OBR. The number of each coding exon and the first nucleotide of each of these exons (according to GenBank accession no. U43168) are indicated above the schematic diagram of OBR with the size of each exon indicated below. The sizes of the two introns between exons 7 and 8 and between 11 and 12 are indicated above. The exons corresponding to those mutated in the fatty rat and diabetes mouse are indicated below. The transmembrane domain is located in exon 16.

quence immediately adjacent to each of the 18 coding exons contained within the long splice variant is shown in Table 1 (GenBank accession nos. U62487-U62521). The exact size of each intron is undetermined, except for the introns between exons 7 and 8, and between exons 11 and 12 , which are 153 and 80 base pairs, respectively.

Two introns were incidentally discovered to contain repetitive sequences. The intron between coding exons 1 and 2 contained a CA repeat of variable length (OBR-CA), and the intron between coding exons 14 and 15 contained a complex CTTT repeat (OBR-CTTT) (Fig. 2). Primers

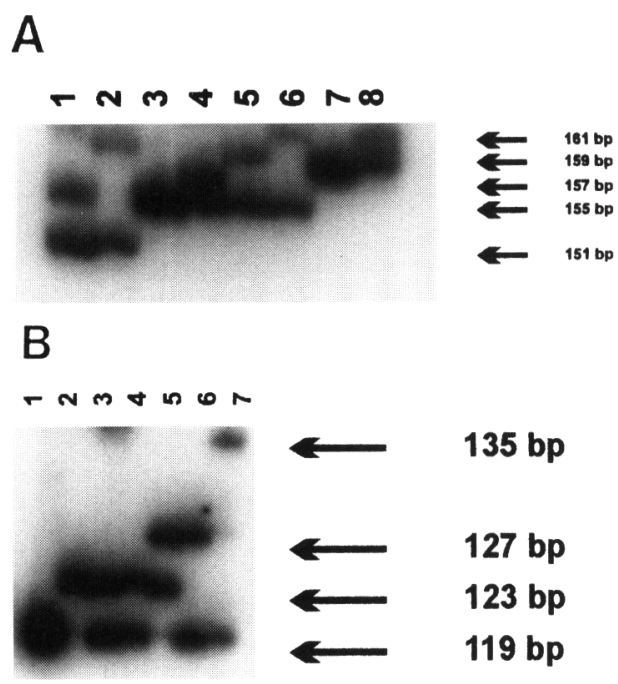

Figure 2 Polymorphic microsatellite markers OBR-CA $(A)$ and OBR-CTT (B). Five different alleles $(151,155,157,159,161 \mathrm{bp})$ of OBR-CA, and four different alleles of OBR-CTTT $(119,123,127,135$ bp) are demonstrated. Two alleles of OBR-CTT migrate at 123 bp but can be distinguished by heteroduplexes on nondenatured gels or by direct sequence analysis (data not shown). flanking the repetitive sequences were designed and used to amplify the regions from 100 unrelated nonobese individuals randomly selected from the New York City population. The heterozygosity scores for OBR-CA and OBR-CTTT were 0.448 and 0.535 , respectively.

\section{DISCUSSION}

Knowledge of the genomic organization of OBR and the intronic sequence adjacent to each of the coding exons for the long form of the gene will enable testing of the plausible hypothesis that allelic variation in OBR contributes to interindividual differences in body fat stores. Additionally, the two highly polymorphic repetitive sequence markers within OBR provide reagents for linkage and association studies that may be performed prior to mutation screening to determine whether variation at the OBR locus is likely to be responsible for variation in body fat in any specific population.

We have analyzed the genomic structure relevant to the OBR splice variant (long form) that is apparently responsible for leptin signal transduction (Ghilardi et al. 1996). However, there are other splice variants for which the terminal coding exon is replaced by a smaller coding exon. Although mutations in these other alternatively spliced terminal exons have not yet been associated with genetic forms of obesity in rodents, it may prove necessary to analyze these alternative terminal exons in the future. For example, a short splice variant may be responsible for transport of leptin across the blood brain barrier (Campfield et al. 1995; Schwartz et al. 1996). Similarly, there is evidence for variability in the $5^{\prime}$ untranslated region (Cioffi et al. 1996). 


\section{CHUNG ET AL.}

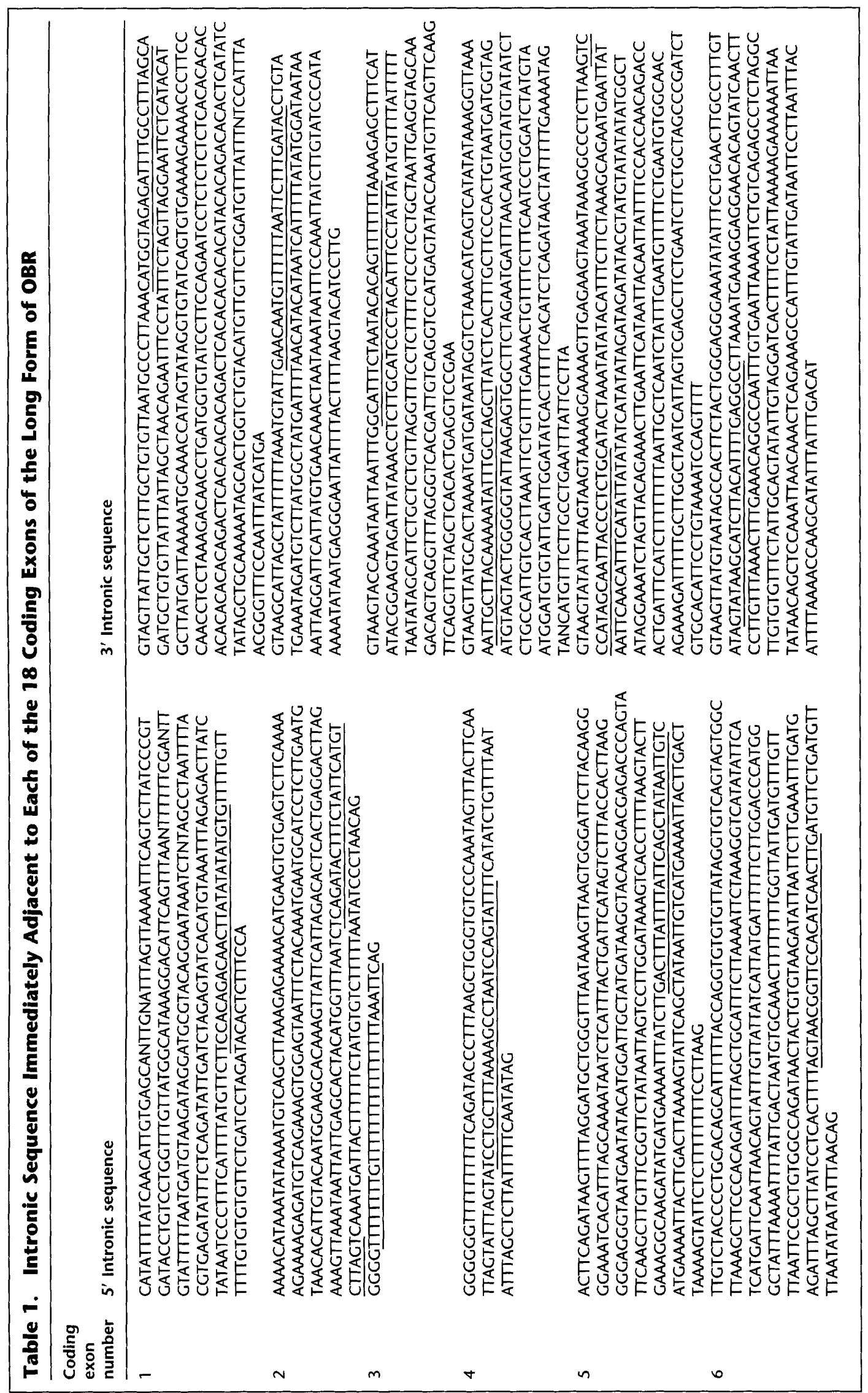




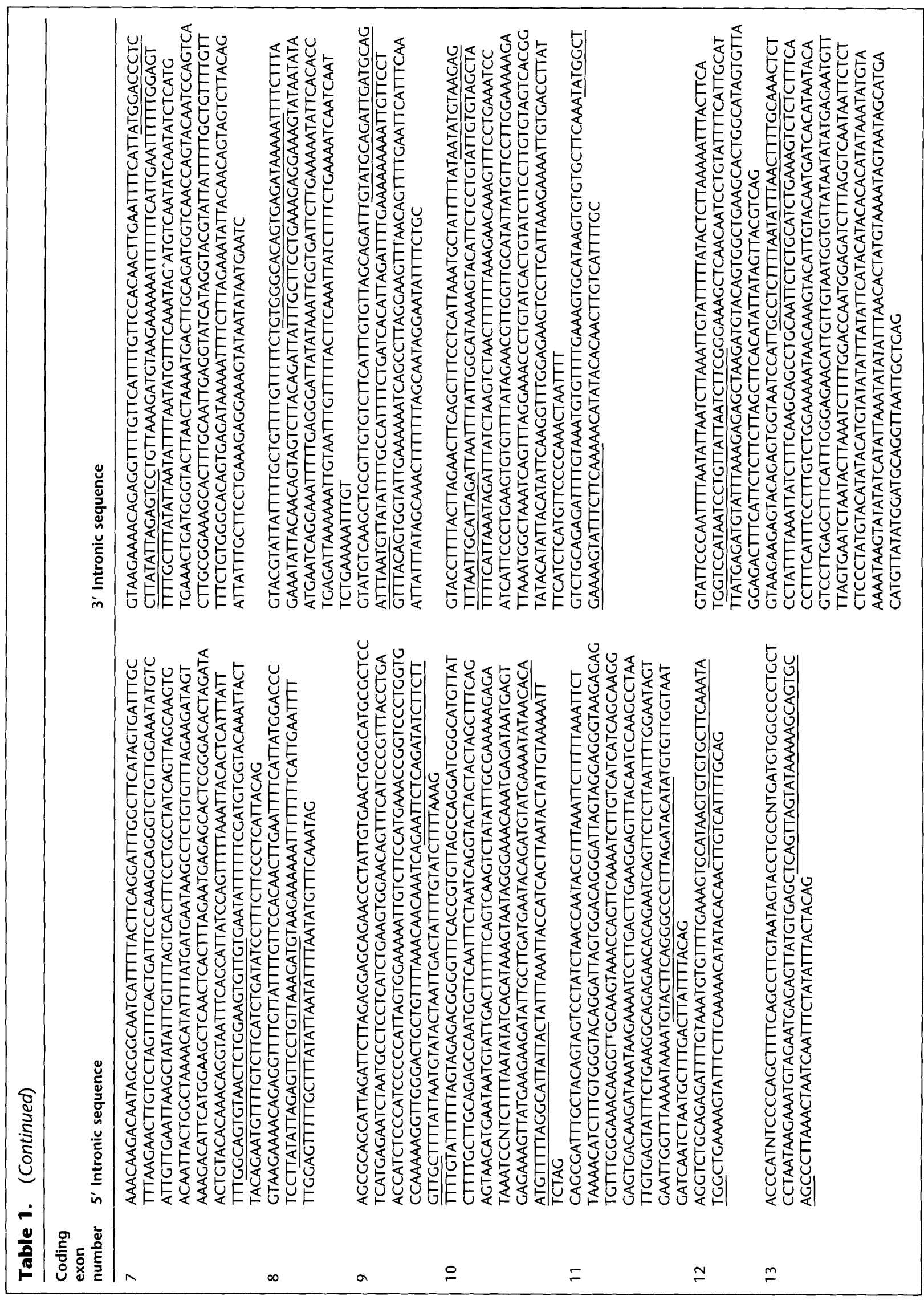




\section{CHUNG ET AL.}

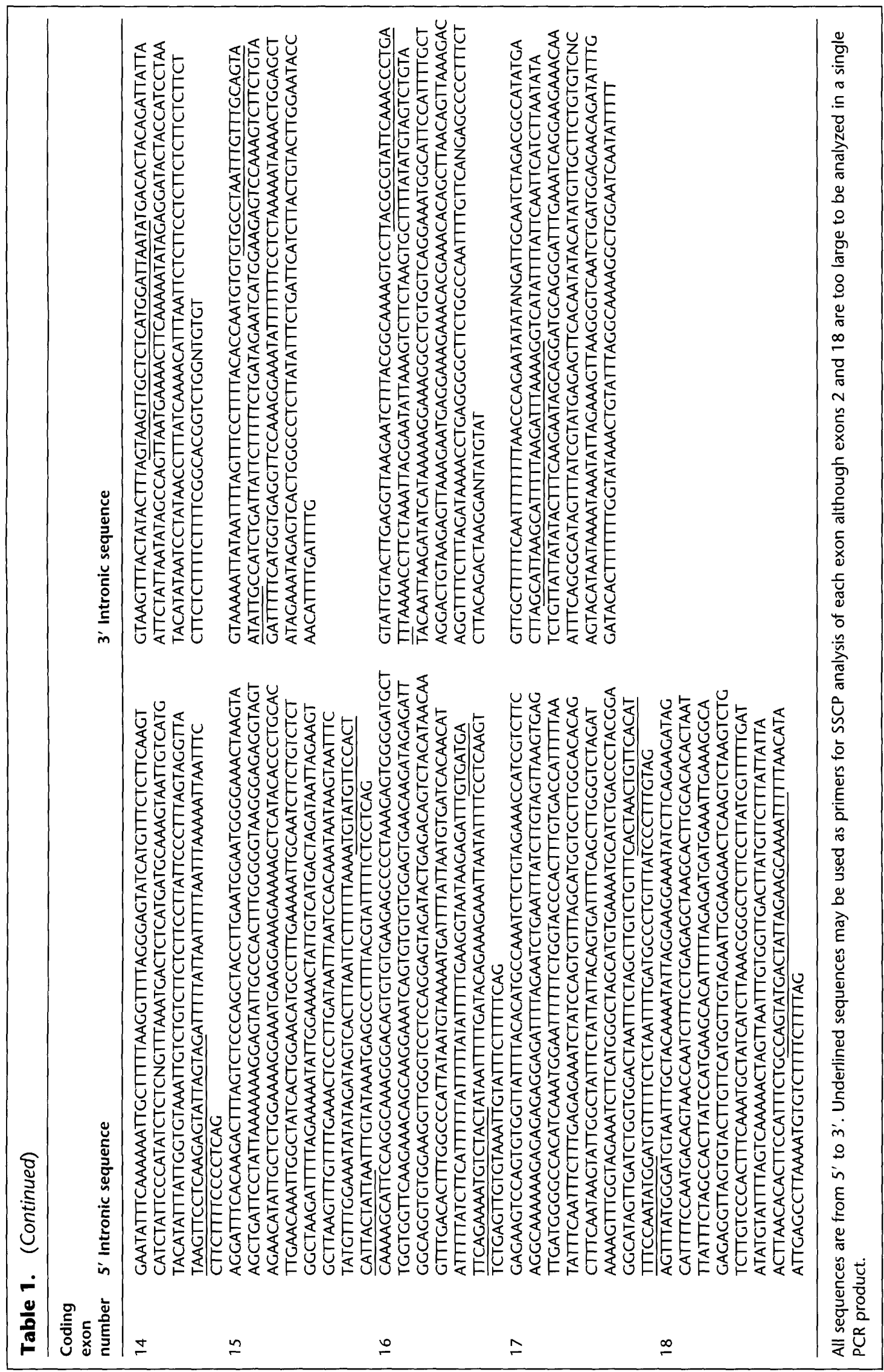


Table 2. Sequences of Nested Primer Sets Used to Define the Boundaries of Each of the 18 Coding Exons and the Adjacent Intronic Sequence

\begin{tabular}{|c|c|c|}
\hline $\begin{array}{l}\text { Location of } \\
\text { intronic } \\
\text { sequence }\end{array}$ & Outer primer & Nested primer \\
\hline on 1 & ITAACAAAACCACACAGAATTTTTG & 5'-AACCACACAGAATTाTGACAAATC \\
\hline & & \\
\hline n 2 & 5'-ATAAGTTAGAAAAGTGAGTACCACTTG & 5'-AAAAGGAAGTAGTCATAGGTTGAAT \\
\hline $3^{\prime}$ of exon 2 & 5'-AATTCGAATGGACATTATGA & 5'-CTGTTGAACCTAAGTTTAATTCAAG \\
\hline $5^{\prime}$ of exon 3 & 5'-CCACATAACAGATGAATAATTITAAG & 5'-TTAGCCAGCACTGTATGTTC \\
\hline exon 3 & 5'-GAACATACAGTGCTGGCTAA & 5'-СТTAAAATTATTCATCTGTTAT \\
\hline exon 4 & GGAGAGTGTCGT & 5' \\
\hline $3^{\prime}$ of exon 4 & 5'-GTGTTCATGAATGTTGTGAAT & 5'-ACGACACTCTCCTТАTGT \\
\hline $5^{\prime}$ of exon 5 & 5'-AGACCCAGGAACTATACTGTCTACTA & 5'-AAGAAATCTTTAAATTACCATCATCT \\
\hline of exon 5 & 5'-AGATGATGGTAATTAAAAGATTCTT & 5'-CACCATTGGTACCATTTCCAC \\
\hline exon 6 & $5^{\prime}-\mathrm{C}$ & 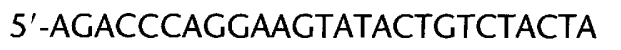 \\
\hline on 6 & 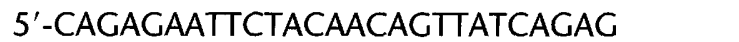 & \\
\hline on 7 & $5^{\prime}-A C$ & TAGGTGGAAAC \\
\hline of exon 7 & ATAACAACCAMAAC & $5^{\prime}$-CAAAAGAGATTGTTTGGTGGATG \\
\hline & $5^{\prime}-\mathrm{CT}$ & $5^{\prime}-\pi T$ \\
\hline & $5^{\prime}-\mathrm{AG}$ & $5^{\prime}-\mathrm{G}$ \\
\hline xon 9 & $5^{\prime}-\mathrm{T}$ & САСТCTGCAAATA \\
\hline $3^{\prime}$ of exon 9 & 5'-ТCСАТСТАТТСАТСССАТАТC & 5'-CAGAGTGATGGTITTIATGAAT \\
\hline n 10 & $5^{\prime}-$ & CCTICA \\
\hline 10 & $5^{\prime}-\mathrm{C}$ & ПTA \\
\hline & $5^{\prime}-A$ & $5^{\prime}-A$ \\
\hline $3^{\prime}$ of exon 11 & $5^{\prime}-A C T C$ & 5'-TACACAGTTGTCATGGATAT \\
\hline of exon 12 & 5'-AAAGTAAAGTGACATTITC & 5'-CATAGTATCTCСATTAATTATTCTCC \\
\hline & $5^{\prime}-$ GGAGAA & 5'-AGGAGAAAAATGTCACTTТССTT \\
\hline n 13 & $5^{\prime}-\pi$ & $C T$ \\
\hline $3^{\prime}$ of exon 13 & $5^{\prime}-\mathrm{AGC}$ & 5'-САААТTTТАТПТААССТПТСАТG \\
\hline $5^{\prime}$ of exon 14 & 5'-ACTTCTTAACAGATGAAGAGATTCT & 5'-АTTTТАTТТСАССАТСТТСАТТАAG \\
\hline of exon 14 & 5'-TTCCTGGATACTATCACCCAG & 5'-CTAATGTATITATTATTGAGTGGAAA \\
\hline exon 15 & 5'-TGAAACTATTAATTATCTTTGGTTTTC & 5'-САСТССТTССАТАAАTATTGGGT \\
\hline ron 15 & 5'-ATCATTTTAT & 5'-GAAAACCAAAGATAATTAATAGTTTCA \\
\hline $5^{\prime}$ of exon 16 & 5'-ATAAGATGGAAGAGGAAATAATTAC & 5'-ATTACATATAAACCTGCATCACTCT \\
\hline $3^{\prime}$ of exon 16 & 5'-AGAGTGATGCAGGTTTATATGTAAT & 5'-GTAATTATTTCCTCTTCCATCTTAT \\
\hline & 5'-AAAATTAAGTCCTTGTGC & 5'-TGCCCAGGAACAATTCTTGGGGTT \\
\hline & 5'-AACCCCAAGAATTGTTCC & 5'-GCACAAGGACTTAATIT \\
\hline $5^{\prime}$ of exon 18 & 5'-CTTTATTTTCCATGATGTATCAACAC & 5'-TGAAATTGTTCAGGCTGGAAAAGAA \\
\hline
\end{tabular}

\section{METHODS}

Generation of Genomic Fragments Defining Splice Sites

The human PromoterFinder DNA walking kit library (Clontech, Palo Alto, CA) was used to generate polymerase chain reaction (PCR) fragments containing the genomic DNA adjacent each exon by performing two long PCR reactions with one of the manufacturer's adaptor primers and one of a set of two nested primers derived from the OBR CDNA sequence. The pairs of nested primers that were used to determine the boundaries of each exon and the adjacent intronic sequence are listed in Table 2. Long PCR reactions were performed in $50 \mu 1$ volumes consisting of $1 \times$ TaKaRa Ex Taq buffer, $200 \mathrm{~mm}$ each dNTP, $100 \mathrm{ng}$ DNA library, $0.2 \mu \mathrm{M}$ adaptor primer 1, $200 \mathrm{ng}$ nested primer, and 2.5 units TaKaRa Ex Taq. Cycling conditions consisted of 35 cycles of $94^{\circ} \mathrm{C}$ for $30 \mathrm{sec}, 55^{\circ} \mathrm{C}$ for $30 \mathrm{sec}$, and $72^{\circ} \mathrm{C}$ for $4 \mathrm{~min}$.

PCR products from the second, nested PCR were electrophoresed through a $2 \%$ agarose gel and stained with ethidium bromide. PCR products were isolated by cutting bands from the agarose gels, centrifuging the DNA through a cotton plug, and removing contaminating primers using Qiagen (Chatsworth, CA) Qiaquick spin pu- 


\section{CHUNG ET AL.}

rification columns according to the manufacturer's instructions.

PCR template ( $250 \mathrm{ng}$ ), $50 \mathrm{ng}$ of primers, and fluorescent terminators were used in a $10 \mu \mathrm{l}$ cycle sequencing reaction electrophoresed on an $\mathrm{ABI} 377$ automated sequencer (Applied Biosystems; Foster City, CA) according to manufacturer's protocols.

Exon junctions were identified as the point at which the genomic sequence diverged from the cDNA sequence reading in both the $5^{\prime}$ and $3^{\prime}$ direction and which contained an adjacent consensus splice site.

\section{Isotopically Labeled Genotyping}

\section{End-labeling}

Forward and reverse primer (100 pmole of each) were endlabeled in a $25 \mu \mathrm{l}$ reaction volume containing 10 mCuries $\left[\gamma^{-32}\right.$ P]ATP, $1 \times$ polynucleotide kinase buffer (New England Biolabs, Beverly, MA), and 20 units polynucleotide kinase for $30 \mathrm{~min}$ at $37^{\circ} \mathrm{C}$.

\section{$P C R$}

PCR reactions for amplification of small fragments including complex repeat sequences utilizing end-labeled primers consisted of $20 \mu \mathrm{l}$ reaction volumes comprised of 100 ng genomic DNA, $1 \times$ reaction buffer supplied by Boehringer Mannheim (Indianapolis, IN) in which the $\left[\mathrm{MgCl}_{2}\right]$ is $1.5 \mathrm{~mm}, 0.25 \mathrm{~mm}$ each dNTP, 30 pmole of each end-labeled PCR primer, and 1 unit Taq polymerase. Primer sequences for the two polymorphic microsatellites were as follows: OBR-CA forward: 5'-GACAACCTGATGGTGTATCCTTC-3'; OBR-CA reverse: 5'-CATCCAGAACAACATGTACAGAC-3'; OBR-CTTT forward: 5'AGAGGATACTACCATCCTAATAC-3'; and OBR-CTTT reverse: 5'-CAACACAACCAGACCGTGCCG-3'. All thermocycling was performed in a Perkin Elmer 9600 with 35 cycles of denaturation at $94^{\circ} \mathrm{C}$ for $30 \mathrm{sec}$, annealing at $55^{\circ} \mathrm{C}$ for $30 \mathrm{sec}$, and extension at $72^{\circ} \mathrm{C}$ for $30 \mathrm{sec}$.

\section{Electrophoresis of Polymorphic Markers}

Five microliters of the PCR reaction was electrophoresed on a $6 \%$ polyacrylamide gel at $60 \mathrm{~W}$ for $2.5 \mathrm{hr}$. Gels were dried and exposed to film.

\section{ACKNOWLEDGMENTS}

We appreciate the technical assistance provided by Camille Commisso and Maria Pospichil with oligonucleotide synthesis and Florence Chu with DNA isolation. This work was supported by National Institutes of Health grants HD28047, DK52431, and DK26687 and the Nutritional Research Institute.

The publication costs of this article were defrayed in part by payment of page charges. This article must therefore be hereby marked "advertisement" in accordance with 18 USC section 1734 solely to indicate this fact.

\section{REFERENCES}

Anon. 1994. Prevalence of overweight among adolescents-United States, 1988-91. Morbidity Mortality Weekly Rep. 43: 818-821.

Bodurtha, J.N., M. Mosteller, J.K. Hewitt, W.E. Nance, L.J. Eaves, W.B. Moskowitz, S. Katz, and R.M. Schieken. 1990. Genetic analysis of anthropometic measures in 11 year old twins: The Medical College of Virginia Twin Study. Pediatr. Res. 28: 1-4.

Bouchard, C. and G.A. Bray, ed. 1995. Regulation of body weight. Report of the Dahlem Workshops on Regulation of Body Weight: Biological and Behavioral Mechanisms. Berlin, May 14-19. John Wiley \& Sons Ltd., Chichester, UK.

Campfield, L.A., F.J. Smith, Y. Guisez, R. Devos, and P. Burn. 1995. Recombinant mouse OB protein: Evidence for a peripheral signal linking adiposity and central neural networks. Science 269: 546-549.

Chen, H., O. Charlat, L.A. Tartaglia, E.A. Woolf, X. Weng, S.J. Ellis, N.D. Lakey, J. Culpepper, K.J. Moore, R.E. Breitbart, G.M. Duyk, R.I. Tepper, and J.P. Morgenstern. 1996. Evidence that the diabetes gene encodes the leptin receptor: Identification of a mutation in the leptin receptor gene in $d b / d b$ mice. Cell 84: 491-495.

Chua, S.C., W.K. Chung, X.S. Wu-Peng, Y. Zhang, S.-M. Lui, L. Tartaglia, and R.L. Leibel. 1996a. Phenotypes of mouse diabetes and rat fatty due to mutations in the $\mathrm{OB}$ (leptin) receptor. Science 27: 994-996.

Chua, S.C., D.W. White, X.S. Wu-Peng, S.-M. Lui, N. Okada, E.E. Kershaw, W.K. Chung, L. Power-Kehoe, M. Chua, L.A. Tartaglia, and R.L. Leibel. 1996b. Phenotype of fatty due to Gln269Pro mutation in the Leptin Receptor (Lepr). Diabetes 45: 1141-1143.

Chung, W.K., L. Power-Kehoe, M. Chua, and R.L. Leibel. 1996. Mapping of the OB receptor (OBR) to $1 p$ in a region of non-conserved gene order from mouse and rat to human. Genome Res. 6: 431-438.

Cioffi, J.A., A.W. Shaper, T.J. Zupancic, J. Smith-Gbur, A. Mikhail, D. Platika, and H.R. Snodgrass. 1996. Novel B219/OB receptor isoforms: Possible role of leptin in hematopoiesis and reproduction. Nature Med. 2: 585-589.

Ghilardi, N., S. Ziegler, A. Wiestner, R. Stoffel, and M.H. Heim. 1996. Defective STAT signaling by the leptin receptor in diabetic mice. Proc. Natl. Acad. Sci. 93: 6231-6235.

Iida, M., T. Murakami, K. Ishida, A. Mizuno, M. Kuwajima, and K. Shima. 1996. Phenotype-linked amino acid alteration in leptin cDNA from Zucker fatty $(f a / f a)$ rat. Biochem. Biophys. Res. Commun. 222: 19-26.

Kuczmarski, R.J., K.M. Flegal, S.M. Campbell, and C.L. 


\section{GENOMIC STRUCTURE OF THE HUMAN OB RECEPIOR}

Johnson. 1994. Increasing prevalence of overweight among US adults: The National Health and Nutrition Examination Surveys, 1960 to 1991. J. Am. Med. Assoc. 272: 205-211.

Lee, G.-H., R. Proenca, J.M. Montez, K.M. Carroll, J.G. Darvishzadeth, J.I. Lee, and J.M. Friedman. 1996. Abnormal splicing of the leptin receptor in diabetic mice. Nature 379: 632-655.

Leibel, R.L., S.C. Chua, and W.K. Chung. 1995. Animal models of genetic obesity. In Progress in obesity research (ed. A. Angel, H. Anderson, C. Bourchard, D. Lau, L. Leiter, and R. Mendelson), vol. 7, pp. 263-217. John Libbey \& Company, Ltd., London, UK.

Phillips, M.S., Q. Liu, H.A. Hammond, V. Dugan, P.J. Hey, C.T. Caskey, and J.F. Hess. 1996. Leptin receptor missense mutation in the fatty Zucker rat. Nature Genet. 13: 18-19.

Schwartz, M.W., E. Peskind, M. Raskind, E.J. Boyko, and J.D Porte. 1996. Cerebrospinal fluid leptin levels: Relationship to plasma levels and to adiposity in humans. Nature Med. 2: 589-593.

Stunkard, A.J., T.T. Foch, and Z. Hrubec. 1986. A twin study of human obesity. J. Am. Med. Assoc. 256: 51-54.

Tartaglia, L.A., M. Dembski, X. Weng, N. Deng, J. Culpepper, R. Devos, G.J. Richards, L.A. Campfield, F.T. Clark, J. Deeds, C. Muir, S. Sanker, A. Moiarty, K.J. Moore, J.S. Smutko, G.G. Mays, E.A. Woolf, C.A. Monroe, and R.I. Tepper. 1995. Identification and expression cloning of a leptin receptor, OB-R. Cell 83: 1263-1271.

Received July 1, 1996; accepted in revised form September 1, 1996. 


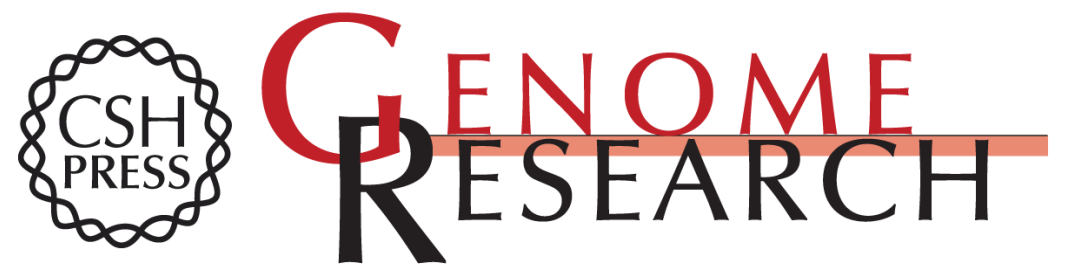

\section{Genomic structure of the human OB receptor and identification of two novel intronic microsatellites.}

W K Chung, L Power-Kehoe, M Chua, et al.

Genome Res. 1996 6: 1192-1199

Access the most recent version at doi:10.1101/gr.6.12.1192

References This article cites 16 articles, 4 of which can be accessed free at:

http://genome.cshlp.org/content/6/12/1192.full.html\#ref-list-1

\section{License}

Email Alerting Receive free email alerts when new articles cite this article - sign up in the box at the Service top right corner of the article or click here.

\section{Affordable, Accurate Sequencing.}

To subscribe to Genome Research go to:

https://genome.cshlp.org/subscriptions 